\title{
Application of the principal component analysis (PCM) as an innovative technology for assessing the morphological and functional state of agricultural poultry with diseases of bacterial genesis
}

\author{
Larisa Lovtsova ${ }^{1, *}$, Sergei Pidenko ${ }^{2}$, Lyudmila Isaicheva ${ }^{1}$, Petr Smutnev $^{1}$, Andrey Shkel ${ }^{1}$ \\ ${ }^{1}$ Saratov State Vavilov Agrarian University, 1, Theater Square, Saratov, 410012, Russia \\ ${ }^{2}$ Saratov National Research State University named after N. G. Chernyshevsky, 83, Astrakhanskaya ave., Saratov, 410012, Russia
}

\begin{abstract}
The possibility of using the method of principal components (PCM) for analyzing the results of hematological studies of blood samples of broiler chickens has been studied. It was found that the graphs of the residual dispersion show a clear clustering of samples into the control and experimental groups after infection in the PC1-PC2 space. The graphs of the scores, built for the higher BG models, showed changes in the values for the GC1 spectrum of leukocytes, and for the GC2 of erythrocytes, hemoglobin. Thus, the use of PCM analysis of hematological blood data makes it possible to separate blood samples from healthy broiler chickens and those susceptible to infection with various infections. PCM is a promising approach for rapid assessment of hematological data.
\end{abstract}

\section{Introduction}

One of the key factors of production efficiency in modern poultry farming is bacterial safety, which plays a basic role.

According to Rosptitsesoyuz data, $60 \%$ is accounted for by the spread of infectious diseases, primarily of a bacterial nature, such as salmonellosis and colibicteriosis [1]. Important features of bacteriological diseases of birds are their associative nature [2], high pathogenicity for human, high liability and adaptability of pathogenic strains in relation to the antibacterial agents used.

Recently, both scientists and poultry practitioners have noted a significant decrease in the effectiveness of antibiotics. Treatment of salmonellosis in chickens is not always effective, since the causative agent of the disease quickly becomes resistant to antibiotics. A sick bird can become a source of infection for humans. Foods eaten can cause severe toxin infection or food poisoning. According to WHO, in a number of infections common to humans and animals, salmonellosis is unmatched in terms of the complexity of the course of the disease and the problems of its elimination.

One of the reasons for such difficulties is the variety of infectious agents - Salmonella microbes. Another difficulty is that salmonellosis in chickens is often asymptomatic. Salmonella, being an inhabitant of the intestines, can get on the shell of eggs and carcasses during slaughter, which, if improperly stored and poorquality processing of farm products, can lead to severe mass poisoning of people.
Cases of infection with Salmonella strains resistant to the main antibiotics have been reported [3-5]. In most cases, the diagnosis of salmonellosis is based on the verification of the pathogen by a bacteriological method, which is performed within 4-5 days, and the detection of antibodies in the passive hemagglutination reaction (RPHA) on the 7th and 14th days of the disease. Late verification of the pathogen using these methods makes it difficult to choose an adequate therapy.

This determines the need to use methods of early diagnosis available for wide practice by changes in blood parameters, its differentiation for the correct choice of an antibiotic.

The purpose of our work was to study the comparative effectiveness of the proposed antibacterial drugs for the treatment of bacterial diseases of birds with data processing by the method of principal components (PCM)

Biological material (blood) for hematological studies was taken in 0.1-0.2 $\mathrm{ml}$ - in microtubes with K2 EDTA anticoagulant for capillary blood; $200 \mu \mathrm{l}$ of "UNIVET" modified "UNIVET-IIm" according to TU 9398-03359879815-2012.

Blood was taken from the jugular vein. Previously, along the course of the veins, the skin was disinfected with a $70 \%$ solution of ethyl alcohol. To obtain serum, samples were centrifuged for $10 \mathrm{~min}$ at $3000 \mathrm{rpm}$.

For the purpose of laboratory confirmation of the diagnosis, biomaterial samples were taken from animals.

To establish the microbial composition of the intestines of the experimental chickens, samples were taken from the cloaca for inoculation on a nutrient

*Corresponding author: Larisalovtsova2018@mail.ru 
medium. Sowing was carried out according to the method of plate sieving on Petri dishes with Endo agar and Bismuth sulfite agar. After incubation of the inoculations at $37^{\circ} \mathrm{C}$ for 2 days, a pure culture was isolated from the grown bacterial colonies. To determine the morphological characteristics of the isolated bacteria, microscopy of bacterial smears with Gram stain was performed.

Determination of the biochemical properties of the isolated bacteria was carried out using the ENTEROtest 24 kit (stripped for the identification of enterobacteria).

The bird was observed daily for 5 days. At the same time, special attention was paid to the behavior and condition of the chickens, the consumption of feed and water, the clinical status, the time of the onset of positive dynamics and the recovery period were assessed.

After the course of treatment on the 5th day, the effectiveness of the drug was evaluated according to clinical signs and according to the results of bacteriological examination of the litter.

\section{Determination of hemoglobin concentration in blood by the hemiglobincyanide method}

The hemiglobincyanide method refers to modern highprecision methods for determining the concentration of hemoglobin in the blood.

Hemoglobin, when interacting with iron-cyanide potassium (red blood salt), is oxidized into methemoglobin (hemiglobin), which forms a colored hemiglobin cyanide with acetonecyanohydrin, the color intensity of which is proportional to the amount of hemoglobin. Determination: $0.02 \mathrm{ml}$ of blood is added to $5.0 \mathrm{ml}$ of transforming reagent in a test tube (dilution 251 times) and mixed well. After 10 minutes, it is measured on a photoelectric colorimeter at a wavelength of $520 \mathrm{~nm}$ (green filter) in a cuvette with a layer thickness of $10 \mathrm{~mm}$ against a blank sample (transformation solution).

\section{Determination of hematocrit}

The hematocrit is the ratio between the volume of blood cells and the volume of plasma. The method for its determination is based on the separation of plasma and erythrocytes using centrifugation. The determination is carried out in a special hematocrine tube, divided into 100 equal parts. Before taking blood, the hematocrit tube is washed with a solution of heparin or oxalate salts ( $0.82 \mathrm{~g}$ of potassium oxalate, $1.2 \mathrm{~g}$ of ammonium oxalate and $100 \mathrm{ml}$ of distilled water). Then, capillary blood is drawn into the tube from a finger to the "100" mark and centrifuged for $1-1.5 \mathrm{~h}$ at $15,000 \mathrm{rpm}$. After that, we note what part (in \%) in the graduated tube are erythrocytes.

The hematocrit indicator is used to calculate the mass of red blood cells circulating in the blood, and some other blood parameters, for example, the average percentage of hemoglobin concentration in one red blood cell and the average volume of one red blood cell [3].

The study of the general blood analysis was performed on an automatic hematological analyzer MicroCC 20 Vet (HTI, US).

Processing of the obtained data by the method of principal components (PCA) was carried out using the Microsoft ${ }^{\circledR}$ Office ${ }^{\circledR} 365$ software package with installed add-ons for Microsoft ${ }^{\circledR}$ Excel: Chemometrix, SIMCA, MulTEx [4,5]

\section{Pharmacological properties of drugs}

We used enrofloxacin (Enrofloxacin manufactured by BiofaktorSp.zo.o., Poland), an antibiotic of the fluoroquinolone group. The mechanism of its bactericidal action is associated with the inhibition of the A subunit of DNA gyrase (topoisomerase II) of bacteria, which blocks the process of supercoiling of the DNA molecule. In gram-positive bacteria, this process affects topoisomerase IV, rather than topoisomerase II. At the same time, reproduction, transcription and recombinant processes in the DNA of bacteria are blocked $[6,7]$.

Enrofloxacin is active against gram-positive and gram-negative microorganisms, such as E. coli, Pasteurella spp., Erysipelothrix rhusiopathiae, Staphylococcus aureus, Streptococcus spp., Mycoplasma spp., Campylobacter spp., Klebsiella spp. other. Enrofloxacin, chemically named 1-cyclopropyl-7- (4ethyl-1-piperazinyl) -6-fluoro-1,4-dihydro-4-oxo-3quinolinecarboxylic acid, is a third generation synthetic quinolone also known as ethylcyprofloxacin.

Kanamycin (Kanamycin manufactured by PHARMASINTEZ, JSC (Russia)) is an antibiotic from the aminoglycoside group, has a bactericidal effect on most gram-positive and gram-negative microorganisms, as well as on acid-fast bacteria, including mycobacterium tuberculosis. It is effective, as a rule, against microorganisms resistant to tetracycline, erythromycin, chloramphenicol. Strains resistant to kanamycin are cross-resistant to streptomycin and neomycin. Anaerobic bacteria, fungi, viruses, and most protozoa do not act on anaerobic bacteria.

The drug belongs to substances of the 4th hazard class - substances of little hazard in accordance with the classification of GOST 12.1.007-76. Has the chemical name 0-3-Amino-3-deoxy-alpha-D-glucopyranosyl- (1 "6) -0- [6-amino-6-deoxy-alpha-D-glucopyranazyl- [1" 4)] - 2 -deoxy-D-streptamine (as sulfate).

To establish the determination of the possibility of using the method of the main components in the processing of hematological data of the blood of broiler chickens of the KOBB-500 cross [8], studies were carried out according to the following scheme:

- We formed 5 groups of broiler chickens, 15 animals in each (tables 1, 2)

The PCM models were studied based on the analysis of data from hematological studies of the blood of broiler chickens from different groups on the first (model I), fifth (model II) days of the study, as well as the entire set of data (model III). The preprocessing of the data 
included a scaling procedure due to the different dimensions of the data.

Table 1. Scheme of infection, formation of groups

\begin{tabular}{|l|l|l|}
\hline No. & Group & Infecting culture \\
\hline 1 & 1 experienced $(n=15)$ & Escherichia coli \\
\hline 2 & 2 experienced $(n=15)$ & Escherichia coli \\
\hline 3 & 3 experienced $(n=15)$ & $\begin{array}{l}\text { Salmonella } \\
\text { enteritidis }\end{array}$ \\
\hline 4 & 4 experienced $(n=15)$ & $\begin{array}{l}\text { Salmonella } \\
\text { enteritidis }\end{array}$ \\
\hline 5 & 5 experienced $(n=15)$ & control \\
\hline
\end{tabular}

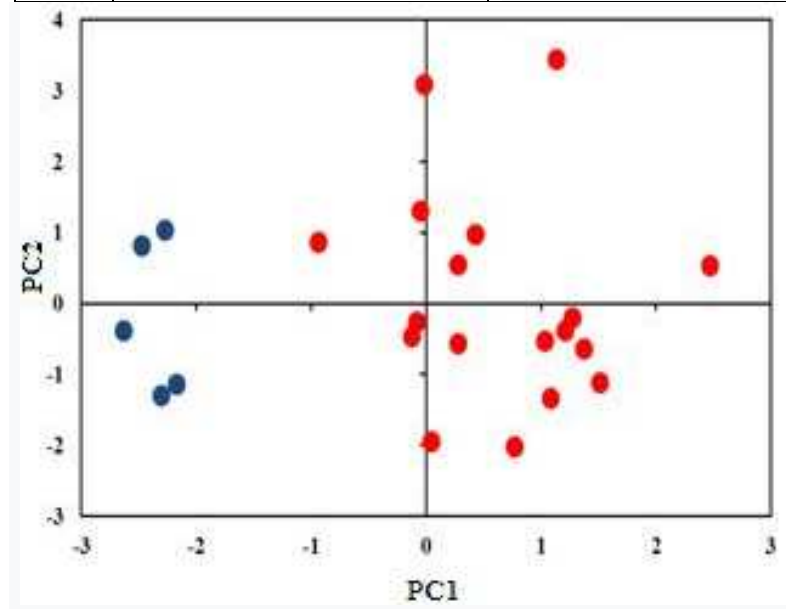

a)

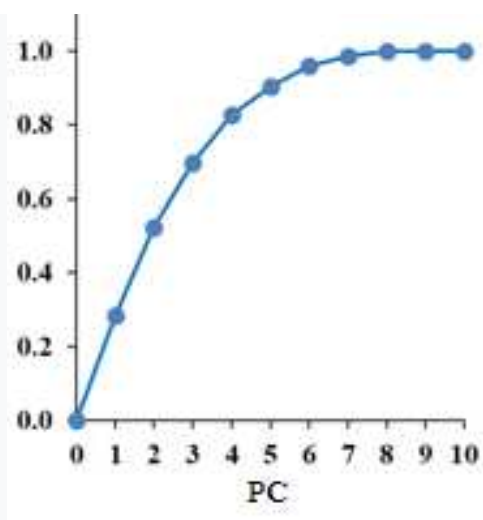

b)

Fig. 1. Model I $(n=23)$. Graphs of scores (a) and residual variance (b) for hematological data of the blood of broiler chickens obtained on the first day of the study. Red - groups 1-4, blue - group 5.

The main results of the PCM analysis are presented in Fig. 1, 2, 3.

Research on the first day - yellow (groups 1,2), brown (groups 3 and 4), blue - group 5, on the fifth day red - groups 1-4, green - group 5.

Residual variance plots show that for a complete description of all PCA models, 5 principal components (PC) are required. However, the clearest clustering of samples into control and experimental groups after infection is observed in the PC1-PC2 space.

Table 2. Study design

\begin{tabular}{|c|c|c|c|c|c|c|}
\hline ڤે & $\begin{array}{l}\text { Kind of } \\
\text { anima }\end{array}$ & $\begin{array}{l}\text { Number of } \\
\text { animals in } \\
\text { the group }\end{array}$ & $\begin{array}{l}\text { Preparation (variant } \\
\text { of experiment) }\end{array}$ & Dose of the drug & $\begin{array}{l}\text { Disease } \\
\text { dying }\end{array}$ & Administration mode \\
\hline 1 & $\begin{array}{l}\text { Broiler } \\
\text { chickens }\end{array}$ & 15 & $\begin{array}{l}1 \text { experienced } \\
\text { Enrofloxacin }\end{array}$ & $\begin{array}{l}2 \mathrm{ml} / 101 \text { of } \\
\text { drinking water }\end{array}$ & $\begin{array}{l}\text { Escherichia } \\
\text { coli }\end{array}$ & $\begin{array}{l}\text { Orally, once a day for } 4-5 \text { days, } \\
\text { depending on the condition of } \\
\text { the animals }\end{array}$ \\
\hline 2 & $\begin{array}{l}\text { Broiler } \\
\text { chickens }\end{array}$ & 15 & $\begin{array}{l}2 \text { experienced } \\
\text { Kanamycin }\end{array}$ & $\begin{array}{l}1 \mathrm{~g} / 101 \mathrm{of} \\
\text { drinking water }\end{array}$ & $\begin{array}{l}\text { Escherichia } \\
\text { coli }\end{array}$ & $\begin{array}{l}\text { Orally, once a day for } 4-5 \text { days, } \\
\text { depending on the condition of } \\
\text { the animals }\end{array}$ \\
\hline 3 & $\begin{array}{l}\text { Broiler } \\
\text { chickens }\end{array}$ & 15 & $\begin{array}{l}3 \text { experienced } \\
\text { Enrofloxacin }\end{array}$ & $\begin{array}{l}2 \mathrm{ml} / 101 \text { of } \\
\text { drinking water }\end{array}$ & $\begin{array}{l}\text { Salmonella } \\
\text { enteritidis }\end{array}$ & $\begin{array}{l}\text { Orally, once a day for } 4-5 \text { days, } \\
\text { depending on the condition of } \\
\text { the animals }\end{array}$ \\
\hline 4 & $\begin{array}{l}\text { Broiler } \\
\text { chickens }\end{array}$ & 15 & $\begin{array}{l}4 \text { experienced } \\
\text { Kanamycin }\end{array}$ & $\begin{array}{l}1 \mathrm{~g} / 101 \mathrm{of} \\
\text { drinking water }\end{array}$ & $\begin{array}{l}\text { Salmonella } \\
\text { enteritidis }\end{array}$ & $\begin{array}{l}\text { Orally, once a day for } 4-5 \text { days, } \\
\text { depending on the condition of } \\
\text { the animals }\end{array}$ \\
\hline 5 & $\begin{array}{c}\text { Broiler } \\
\text { chickens }\end{array}$ & 15 & 5 experienced & & control & \\
\hline
\end{tabular}


Table 3. Hematological parameters of the blood of broiler chickens $(n=5, P \leq 0.05)$

\begin{tabular}{|c|c|c|c|c|c|c|c|c|}
\hline \multirow[t]{2}{*}{ No. } & \multirow[t]{2}{*}{ Indicators } & \multirow{2}{*}{$\begin{array}{l}\text { Experiment } \\
\text { days }\end{array}$} & \multicolumn{6}{|c|}{ Experimental group } \\
\hline & & & $\begin{array}{c}\mathbf{1} \\
\text { experienced }\end{array}$ & $\begin{array}{c}\mathbf{2} \\
\text { experienced }\end{array}$ & $\begin{array}{c}\mathbf{3} \\
\text { experienced }\end{array}$ & $\begin{array}{c}\mathbf{4} \\
\text { experienced }\end{array}$ & $\begin{array}{c}\mathbf{5} \\
\text { experienced }\end{array}$ & Norm \\
\hline 1. & $R B C, 10^{12} / \mathrm{L}$ & 1 & $4,6 \pm 0,2$ & $4,5 \pm 0,2$ & $5,1 \pm 0,2$ & $5,7 \pm 0,2$ & $2,8 \pm 0,1$ & $2,8-4,2$ \\
\hline 2. & & 5 & $3,9 \pm 0,2$ & $2,9 \pm 0,09$ & $2,9 \pm 0,1$ & $1,9 \pm 0,1$ & $2,8 \pm 0,1$ & \\
\hline 3. & $H G B, g / L$ & 1 & $77,9 \pm 7,3$ & $75,8 \pm 7,7$ & $62,6 \pm 14,5$ & $68,6 \pm 14,1$ & $88,6 \pm 5,5$ & $80-100$ \\
\hline 4. & & 5 & $74 \pm 8,9$ & $80,8 \pm 5,6$ & $77,8 \pm 6$ & $81,6 \pm 6,2$ & $91,4 \pm 9,9$ & \\
\hline 5. & $W B C, 10^{9} / L$ & 1 & $32,9 \pm 0,6$ & $33,1 \pm 0,9$ & $31 \pm 0,5$ & $34,8 \pm 0,9$ & $24,3 \pm 0,4$ & 20-30 \\
\hline 6. & & 5 & $23,9 \pm 1,1^{*}$ & $24,1 \pm 1,1 *$ & $25,3 \pm 0,5^{*}$ & $24,2 \pm 0,6^{*}$ & $23,4 \pm 0,8^{*}$ & \\
\hline 7. & $\begin{array}{l}\text { Pseudo-eosinophils } \\
\%\end{array}$ & 1 & $30 \pm 1,9$ & $30,6 \pm 1,6$ & $29,5 \pm 2,6$ & $30 \pm 1$ & $28,4 \pm 2,9$ & 18-30 \\
\hline 8. & Eosinophils, $\%$ & & $8,2 \pm 1,5$ & $8,1 \pm 1,1$ & $8,8 \pm 0,6$ & $8,9 \pm 0,6$ & $6,8 \pm 0,9$ & $1-8$ \\
\hline 9. & Monocytes, \% & & $3,1 \pm 0,5$ & $4,4 \pm 1,6$ & $3,9 \pm 0,1$ & $4,4 \pm 1$ & $4,7 \pm 0,7$ & $1-6$ \\
\hline 10. & Basophils, \% & & $0,9 \pm 0,2$ & $1,2 \pm 0$ & $1,4 \pm 0$ & $1,1 \pm 0$ & $0,4 \pm 0$ & $0-1$ \\
\hline 11. & Lymphocytes, \% & & $71,5 \pm 2,1$ & $70,9 \pm 1,2$ & $73,6 \pm 2,3$ & $72,8 \pm 1,1$ & $58,5 \pm 3,7$ & $52-67$ \\
\hline 12. & $\begin{array}{l}\text { Pseudo-eosinophils } \\
\text {,\% }\end{array}$ & 5 & $30,5 \pm 2,5$ & $29 \pm 2,5$ & $28,5 \pm 1,1$ & $29,4 \pm 4,6$ & $29,3 \pm 1,8$ & $18-30$ \\
\hline 13. & Eosinophils, \% & & $4,9 \pm 1,6$ & $6,1 \pm 0,2$ & $6,2 \pm 1,3$ & $7,2 \pm 0,4$ & $6,4 \pm 1,2$ & $1-8$ \\
\hline 14. & Monocytes, \% & & $3,9 \pm 1,5$ & $4,1 \pm 0,5$ & $3,9 \pm 0,8$ & $4,9 \pm 0,4$ & $4,6 \pm 1,2$ & $1-6$ \\
\hline 15. & Basophils, \% & & $0,4 \pm 0$ & $0,4 \pm 0$ & $0,4 \pm 0$ & $0,5 \pm 0$ & $0,4 \pm 0$ & $0-1$ \\
\hline 16. & Lymphocytes, $\%$ & & $60,1 \pm 1,6$ & $60 \pm 2,3$ & $60,6 \pm 1,5$ & $57,7 \pm 4,2$ & $59 \pm 2,4$ & $52-67$ \\
\hline
\end{tabular}

Note: * The difference is statistically significant between the experimental and control groups $(P \leq 0.05$ at $t$ critical 2.10$)$.

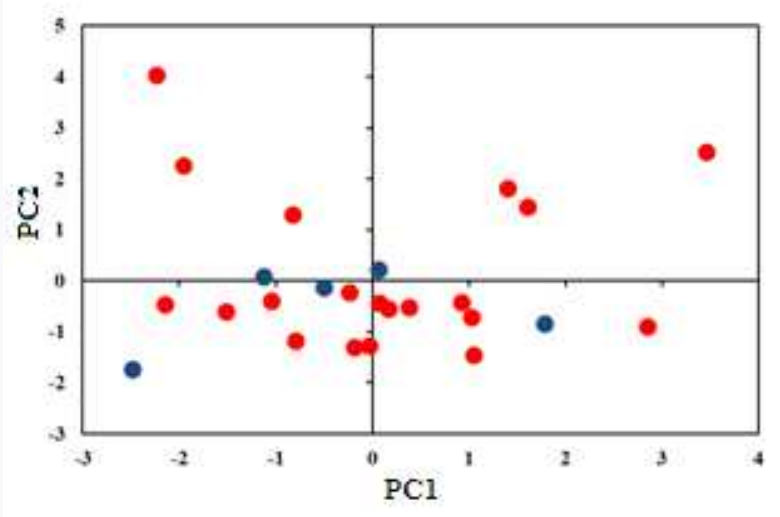

a)

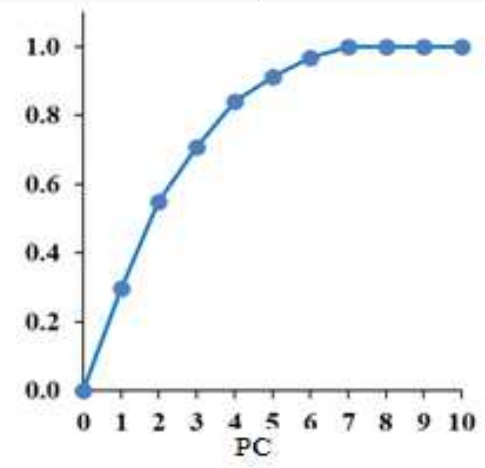

b)

Figure 2. Model II $(\mathrm{n}=25)$. Graphs of scores (a) and residual variance (b) for hematological parameters of the blood of broiler chickens obtained on the 5th day of research. Red - groups 1-4, blue - group 5.
The graphs of scores, built for higher BGs, showed changes in the values for the GC1 spectrum of leukocytes, and for the GC2 of erythorocytes and hemoglobin. At the same time, according to the load graphs (models I and III), changes in the values of lymphocytes correspond to the distribution of samples in the PC1-PC2 space for the healthy and sick groups according to $\mathrm{PC} 1$, and changes in the values of erythrocytes and hemoglobin for PC2.

The number of blood lymphocytes of animals of all groups was within the normal range or slightly higher than the reference values. That is, they did not reveal clinical signs of diseases, although the number of blood lymphocytes of infected chickens was 1.05 times higher than that of intact chickens.

Our data correlate with the results obtained during the treatment of PCA and indicate a change in the homeostasis of the organism of infected animals even in the absence of clinical signs of the disease.

There were no significant differences in the data of hematological parameters of the blood of broiler chickens after their infection with colibacillosis and salmonellosis.

Scoring charts for models II and III show that treatment of broiler chickens for 5 days leads to an equalization of hematological blood parameters and does not allow them to be divided into separate groups. This fact may indicate their successful treatment. 


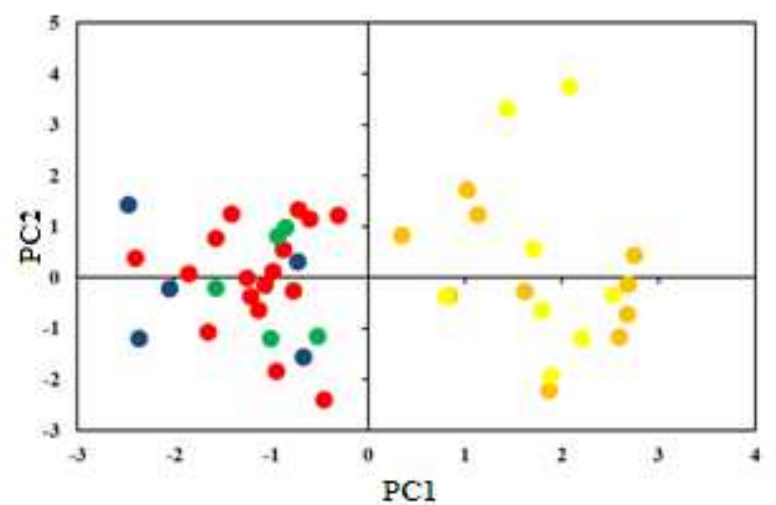

a)

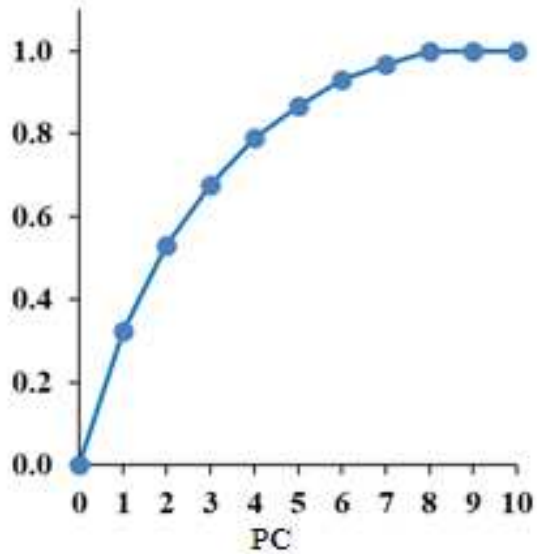

b)

Figure 3. Model III $(\mathrm{n}=20)$. Graphs of scores (a) and residual variance (b) for hematological parameters of broiler chickens in dynamics.

\section{Conclusion}

Thus, the use of PCA analysis of blood plasma biochemical data makes it possible to separate blood plasma samples from healthy broiler chickens and those susceptible to infection with various infections. PCA is a promising approach for rapid assessment of biochemical data.

\section{References}

1. L.A. Vengerenko, Veterinary and sanitary provision of epizootic well-being in poultry farms of the Russian Federation - VII, 3. 1 E 38-41 (2018)

2. M.A Volkova, P.S Yaroslavtseva, V.Yu. Sosi Pato Rova, T.L. Eroshina, I.A. Chvala, Study of pathogenesis and immune response at experimental infection of broiler chicks with avian metapneumovirus subtype B, Veterinary Science Today, 4, 29-34 (2016)

3. A.L. Pomerantsev, Chemometrics in Excel (Simplified Chinese) (Chemical Industry Press, Beijing Shi, Excel, 2018)

4. A.L. Pomerantsev, O.Ye. Rodionova, Abnormal View of Linearity, in: 13th Scandinavian Symposium on Chemometrics, Sardinia, Italy (2015)

5. C. Malegori, P. Oliveri, A. Pomerantsev, O. Rodionova, Conference report: The first "food and drug testing workshop" (FDT-2018), 12-14 December, Genoa, Italy, Food Chemistry, 292, 106107 (2019)

6. O.I. Guliy, B.D. Zaytsev, I.A. Bopodina, A.A. Teplyx, O.V. Ignatov, Acoustic method for the analysis of bacterial cells, Biophysics, 744-757 (2016)

7. O.I Gulij, O.A. Karavaeva, V.A Velikov, O.I. Sokolov, S.A. Pavlij, O.S. Larionova, A.M. Burov, O.V. Ignatov, Study of the adsorption of bacteriophage $\mathrm{FAb}-\mathrm{Sp} 7$ on the cell surface of Azospirillum brasilense Sp7, Virology Issues, 61(1), $45-48$ (2016)

8. I.V. Lovtsov, K.Yu Uskov, M.V. Zabelina, L.G. Lovtsova, Dependence of the growth rate of broiler chickens with the combined use of ionophore coccidiostatics with macrolides, in: Materials of the National scientific and practical conference with the participation of the international, Saratov SAU named after N.I. Vavilov, pp. 85-89 (2020) 